\title{
PREFERENCES OF CUSTOMERS AND IMPROVEMENT OF PRODUCTION AND SALES OF ORGANIC PRODUCTS IN SERBIA
}

Goran Dašić ${ }^{1}$, Adriana Radosavac ${ }^{2}$, Desimir Knežević3 ${ }^{3}$ Ružica Đervida ${ }^{4}$

*Corresponding author E-mail: adrianaradosavac@gmail.com

A R T I C L E I N F O
Original Article
Received: 01 March 2019
Accepted: 21 March 2019
doi:10.5937/ekoPolj1901127D
UDC 658.8.012/.013:631.147(497.11)

Keywords:

organic farming, internet, marketing, incentives to agriculture

JEL Q013

\section{A B S T R A C T}

Promotion and sale of organic products require particular approach to introduce customers about the branding, packaging and advantages in comparison to conventional products. The aim of work is investigation which are sources of promotion of organic products use customers and effects of sources on trade improvement. In this study conducted interviews of 400 of customers through the mail. The results showed differences among customers according to: sources of their information about traits of products and market place, and their behavior and decision for use of organic product. Women more often use electronic media, professional literature, while man use magazine as a source of information. Both gender, male and female used internet equally. Customers old between 21 and 40 years more often bought in supermarkets and specialized stores, while customers of age between 41 and 60 years more often bought directly on market from producers. Customers who have more than 60 years buy on the market from producers and the supermarket. This differences depends of gender, age, education, as well as place of residence of customers

(C) 2019 EA. All rights reserved.

\section{Introduction}

Organic agriculture is production system without the use of artificial substances for increased productivity that sustains the health of soils, ecosystems and people. Organic

1 Goran Dašić, High School of Modern Business, Terazije 27, Belgrade, Serbia, E-mail: goran.dasic@mbs.edu.rs, ORCID ID: https://orcid.org/0000-0002-9001-7468

2 Adriana Radosavac, University Business Academy in Novi Sad, Faculty of Applied Management, Economics and Finance in Belgrade, Jevrejska 24, 11000 Belgrade, Serbia; E-mail:adrianaradosavac@gmail.com, ORCID ID: https://orcid.org/0000-0001-8639-6189

3 University of Pristina, Faculty of Agriculture, Kosovska Mitrovica-Lesak, Kopaonicka bb.,38219 Lesak, Kosovo and Metohija, Serbia, deskoa@ptt.rs, ORCID ID: https://orcid. org/0000-0001-8471-9060

4 Independent Universities of Banja Luka, NUBL, Banja Luka, Veljka Mlađenovića 12e, 78000 Banja Luka, Republic of Srpska, E-mail:ruzica.djervida@gmail.com, ORCID ID: https://orcid.org/0000-0003-2880-6324_ 
farming is sustainable production system of quality health-safe strictly controlled, certified food from farm to table, in order to satisfy the desires and needs of consumers, achieving economic and ecological profits and environmental protection (Babović, 2008).

Organic farming promotes agro-viable biological cycles and soil biological activity (Phillip \& Dipeolu, 2010).

Organic farming in Serbia is in development which focused on promotion of sustainable lifestyle while preserving the environment. In Serbia, there is considerable potential for the production of organic feed (geographical position and moderate continental climate, soils on which long-term was not applied chemicals, preserved biodiversity, and qualified human resources for agricultural production and food trade), Sudarević (2005).

Organic production in Serbia in 2015 - 2016, was carried out on a total area of 15.298 hectares (including meadows and pastures), including surfaces that are certified as organic and other in conversion period. Total surface area increased by 62 percent in comparison to 2014 was 9,548 hectares with trend of increasing (Zarić \& Mijajlović, 2014; Simić, 2017).

The organic food products offer profitable business opportunities as they fetch a higher price than conventional food product in the domestic as well as export markets. For increasing of organic production and sale of organic products is very important market development, market access, and marketing techniques with a strong focus on marketing for export purposes.

One single farm or individual producer is not able to supply the volume required by the market, as well to achieve product development, branding and effective promotion (Schmid, et al. 2004). However, traders can promote organic products and provide access to clients and markets. There are international standards and private guidelines, which regulate the socio-economic dimensions of trade. The each market characterized of the local economy, demographics, accessibility and information on potential local competitors.

The information about the organic product which can be purchased by single people, families with children, people with a high or low income, people that highly educated or less educated, can often be found in market research studies published on the Internet, books, periodicals or newspapers. There are different instrument of promotion of organic products that have influence on consumers to determine for purchase. Demand for organic products is increasing all over the world due to changes in consumer lifestyle and eating habits. Consumers have more information about the food market and are becoming more concerned about living healthily (Grubor \& Djokić, 2016). Therefore, producers should be more focused on consumer perceptions towards organic products in order to meet consumers' needs (Schleenbecker \& Hamm, 2013; Xie et al., 2015; Golijan \& Dimitrijević, 2018). 
The Prospects of development of organic food production in Serbia can estimate on the base of state support to this form of production and requirements of customers on market for organic products.

State incentives are very modest in both for agricultural production and for sale and distribution of products. Therefore many manufacturers of need plan additional time and finances for organization of product placement, alone or through association with other producers by linking with small, medium and large systems of suppliers and distributors.

In numerous of national strategies are promotes organic agriculture as a fast-growing and profitable business, but at the same time insufficient attention is paid to its peculiarities.

In Serbia, declared the Law for Organic Production (in 2010 and a series of regulation established the production of agricultural products and other organic products by methods of organic production, processing, storage, labeling, transport, certification and marketing of products) in order to obtain a product with a confirmed procedure of production, consumers protection, environmental protection, protection of natural resources from pollution, increase soil fertility (The Official Journal RS, no. 30/10, 2010).

The aim of work is investigation which are mode of information and sources of promotion of organic products use customers and how is potential effect of promotion model on trade improvement of organic products.

\section{Advantages of organic agriculture}

As defined by the FAO (Food and Agriculture Organization of the United Nations at the UN) and WHO (World Health Organization), "Organic agriculture is a production management system that promotes the recovery of ecosystems, including biodiversity, biological cycles and emphasizes the use of methods that largely exclude the use of inputs outside farm." (FAO/WHO 1999).

The organic production is important for utilization of renewable energy sources, maintenance and agro-ecosystem, environment, reduction of all forms of pollution, that occur in conventional agriculture. Also, many farmers accept organic farming as a way to increase their income due to public policy support and growing market demand. The organic production method allows the rational use of resources and energy to ensure protection of natural resources for future generations (Bozic \& Vega Garcia, 2013).

Accordingly, "organic product is any product produced and labeled in accordance with the law and regulations based on it" (The Official Journal RS, no. 30/10, 2010).

The main goals of organic products are the production of health food without the use of synthetic chemical insecticides, fungicides, herbicides, synthetic fertilizers, additives, growth regulators, hormones, antibiotics and GMO. The end of twentieth and the beginning of the twenty-first century was rich with the programs and actions 
in the field of the protection, revitalization and improvement of the environment (Kovačević, 2011).

The development of organic production affected by knowledge, education and training for producers, the development of processing, association of producers, processors, contracting production for known buyer, production and certification of products, agro economic politics, business associations and the use of IPARD funds of the EU in development of organic agriculture.

The development of organic production in Serbia is limited due to the effect of several factors: (Vlahović, et al. 2010).

- decline in living standards and reducing the purchasing power of the population, which resulted in the decrease of demand for organic food;

- low level of environmental awareness and the culture of life; and

- insufficient funding and support from the state

Eating of organic food means a return to nature, a healthy lifestyle and traditional values.

Many marketing experts are studying and investigating the tendency of the market especially in the case of organic food. There are three groups of consumers interested in organic food: one group that prefers organic products for health reasons, the other group that wants to improve and maintain their health and that of their families and a third group of people who tried to propagate back to the rural areas in the aim of revival of the village and engage in healthy physical culture.

For increasing of interest for organic food in consumers, it is necessary establish marketing strategies. Firstly we have to have make influence on consumers to change their habits of diet and that determine healthier foods. The process is long-term, because there is a doubt and distrust to the changes of behavior in majority of consumers. Therefore, the role of marketing strategy must related to education of the people and their determination.

In some studies it has been shown that most people are determined for organic foods only when faced with health problems. In fact, consumers search for organic food in order to maintain their health (Dumea, 2012; Petrescu et al., 2017; Smith-Spangler et al., 2012; Rosona \& Gebresenbet, 2018).

The function of marketing strategy should be reflected in supporting the changes and motivation of consumers to accept changes in diet in the aim of improving quality of life style and harmonization of mind, body, health, need, desires and interest of consumers.

\section{The characteristics of the market for organic products in the Republic of Serbia}

The first business of organic farming in Republic of Serbia, began the company Den Juro with forming plantation of fruit in Blace in 1989. The first shipment of organic fruit, company is exported after (Kalentić, et al. 2014). 
Developing of organic production is influenced by awareness of consumers about the importance and benefits of organic food, which led to the increasing of interest in this type of product (Sudarević, et al. 2011; Xie et al., 2015).

However, a significant increase in demand for organic products is recorded only since 2000 year. That was result of the numerous projects that had various international organizations (GIZ from Germany, Avalon from the Netherlands, SIDA of Sweden and others) that were conducted with the aim of improving organic production and promotion of organic products.

Sales of organic products is organized so that most organic products are sold to wholesalers and processors, while only $20 \%$ of producers are sale directly on market (Oljača, 2015). One of the problems that producers of organic food have today is lack of storage space. Therefore, the majority of organic agricultural products is available only in season.

The global economic crisis has negatively affected the economic trends in Serbia. The decline in living standards as a result of recession in which the economy in the Republic of Serbia has contributed to reducing the demand for organic products. Furthermore, the higher prices of organic products compared to products produced in conventionally production was too big a burden for household budgets.

Reduced demand for organic products has affected the decrease in production, which was reflected to the market of the Republic of Serbia with greater occurrence of imported products compared to products produced by domestic manufacturers.

In extensive research about customers' demands and consumption of organic agro-food products in all over the world were found that price is one of the limited factor (Willer $\&$ Lernoud, 2014). This indicates that organic farming can be a driving force not only the development of agriculture, but also the economy in general.

\section{The local market for organic products}

The great awareness about importance of organic food is existing among consumers living in urban areas. This is result of increasing offer on market and availability of organic products in retail stores, especially supermarkets. The offer of organic food existing in majority of chain stores in Republic of Serbia, Those products are exposed to special shelves marked as space with offer organic product how can be more visible for customers. Progress in promoting organic products is the promotion of the national sign of origin, that guarantee of quality and recognition of organic products.

Serbia Organica has implemented a promotional campaign in retail shopping facilities in aim of raising consumer awareness about the importance of organic products for health and contribution of organic production to preservation of the environment.

In Republic of Serbia, consumers of organic products can buy in supermarkets, specialized shops and in market place. The purchasing on the market place connected 
with difficulties related to freshness of products, organoleptic properties of product, and information about production and producers. Consumers in Serbia generally not possess enough knowledges about organic products advantages, technology of production and in addition have no confidence in certificates (Vlahović et al. 2010).

For this reason, it is necessary to introduce the standard of a control of the products from the field to the table and preventing an unexpected accident (ISO 9000: standards for quality management system; ISO 14000: systems of management of environmental protection; ISO 22000: food safety management system; BRC: standard production of processed food and services; IFS: international food standard, HALAL: system of food production and processing; Kosher: the system of production and preparation of food; GOST-R: the standard of the food product; GLOBALG.AP: standard of good agricultural practices; HACCP: system for analysis of risk and management of processes at critical control points; Organic (BIO) Certificate: Certificate for organic production and products; PGI / PDO: certificate of protection of geographical origin, names, sign).

The greatest demand for organic products is in bigger cities due to higher purchasing power. In offer of large retail chains in Serbia (Tempo, Maxi, Univerexport, Idea, DIS, Aman, Sunce), organic products are exhibited on separate special shelves that contain specific types of products (for example: flour without gluten, grains, unrefined vegetable oils cold-pressed, thermally processed products such as jam, sweet, pastries with seeds, unfermented biscuits etc).

In research of Vlahovic et al. (2013) the main motives for the purchase and consumption of organic food are:

- $\quad$ taste: many people buy organic food because they believe that it tastes better than conventional, and better for health.

- health: in average, organic food contains higher levels of vitamin $\mathrm{C}$ and mineral elements (calcium, magnesium, iron) as well as antioxidants.

The appearance of these supermarkets launched a rise in food prices, while producer prices declined. Michelsen et al. (1999) in their analysis of complex organic European market at the beginning of the nineties of 20 century, found that the development of market of organic food is in strong relation to high levels of sales in supermarkets.

In small communities, smaller domestic retail chains also following this trend by exhibition of organic food at visible places for customers and mark of promotion of local producers.

\section{Problem and hypothesis}

In this work were conducted study about importance and value of organic products at the customers opinion, theirs habit of purchase, which is source of information or level of knowledge about organic products and satisfaction with organic products. 
Research hypotheses are defined as:

- $\quad$ Consumers prefer to purchase organic products, with particular purchasing habits, information and satisfaction concerning these products.

- $\quad$ Consumer behavior in relation to organic products is conditioned by their socio-demographic characteristics.

\section{Materials and methods}

In this study were investigated the level of information of customers about the market and the interest of buyers of organic products in Serbia, as well as ways to promotion organic products.

The questionnaire was sent by e-mails to 400 consumers in Belgrade region from 05 to 31 January 2019.

The questions are designed in a way that even very short answers are sufficient to form a specific thesis, and estimation of the situation on the ground. The main purpose of the research was to determine how the market is interested in organic products and informed about the benefits, which forms of promotion proved to be the best and to what extent organic food production sustainable and profitable business in Serbia, and what measures can be taken to the population to a large extent interested in these products.

The questionnaire was compiled by researchers which contained 18 questions that include demographic characteristics of the customers, their attitude towards organic products, buying habits, information and satisfaction market organic products. Completing the questionnaire was anonymous.

The study included a total of 400 customers, of whom $37.1 \%$ male and $62.9 \%$ female customers. The sample included different age groups, ranging from 21 years to a category that includes more than 60 years.

Distribution in percentages is as follows: first age group 21-30 has a share- $29.6 \%$; second age group 31-40 has a share-24.4\%; third age group 41-50- has a share 28,2\%;fourth age group 51-60 has a sharp $-11.7 \%$ and fifth age group over the 60 year has a share - $6.1 \%$. The most of customers had completed secondary education $(54.5 \%)$, followed by high school or college $(34.3 \%)$. While a smaller percentage of customers completed only elementary school (1.4\%), or master, master and doctoral study (9.9\%)

The less than $2 / 3$, or $60.6 \%$ of the customers live in the urban area, while $39.4 \%$ are stationed on the outskirts of the city. The most of the customers were employees $(71.4 \%)$, followed by students $(16 \%)$, unemployed $(6.6 \%)$ and pensioners $(6.1 \%)$.

The obtained data about answers of customers were studied by using descriptive statistics and Chi-square test. For statistical analysis used program, IBM SPSS 20. 


\section{Results}

The customers, throughout the survey, answered on series of questions to determine the way in which they see and consume organic products. It turned out that $71.8 \%$ of customers preferred to use organic than conventionally produced products. However, more than half customers that they seldom buys organic products $(46 \%)$ or they do not buy $(8.5 \%)$ - a total of $54.5 \%$. The smallest number of customers always buys organic products $-2.3 \%$, while $43.2 \%$ of them often buy.

The largest number of customers purchase organic products in supermarkets $(30.5 \%)$, on market places $(25.4 \%)$ and in specialized shops $(23.5 \%)$. Significantly less number of customers purchase organic products directly from the manufacturer $(14.1 \%)$ or online $(6.6 \%)$.

The reasons which customers the most encouraged to purchase organic products are next: the primary health care $(29.6 \%)$, the desire to consume quality food $(28.6 \%)$, better taste (14.6\%), and at the end of eco-friendliness (7.5\%). A fifth of customers indicated none of the above reasons and the assumption is that these are people who do not prefer organic produce and rarely buy those (19.7\%).

When consumers make decision to purchase organic products they take into account the reliability of the manufacturer about $38 \%$, and the price about $23 \%$. The $25.4 \%$ of customer answered that for them is the most important personal preferences. Fewer number of consumers cited as an important assortment (10.3\%) and location (3.3\%).

In addition, the characteristics of the product that are significant for customers are primarily related to reputation (in $25.4 \%$ of cases) and the recommendations of others (33.3\%). Fewer number of customers make decision depending on the price $(19.7 \%)$, brand $(10.3 \%)$ and advertising $(8.9 \%)$ while the lowest depending on the packaging $(2.3 \%)$.

The majority of consumers $61 \%$ believe that is partly informed about characteristics of organic farming. Significant number of the sample of customers stated that it is fully informed $-17.4 \%$. A smaller number interviewed customers is not informed $-9.4 \%$ while $12.2 \%$ of customers cannot say with certainty whether are informed. Moreover, the Internet plays an important role in informing customers about organic products. A third of customers said that it internet is primary tools of information (34.3\%), a slightly smaller number of customers are informed by using electronic media $(23.9 \%)$ and from people in environment $(23 \%)$.

Approximately equal number of customers use professional literature and magazines for information about organic products. Although the Internet is the primary medium for informing customers about the organic products they are accessing the media critically.

Of the total sample - $20 \%$ of customers stated that information from the Internet significantly affect to level of information about organic products, $33.8 \%$ of customers said that the Internet affects little or no impact, and $46 \%$ have a relative impact. The most of the customers find information on websites (45.1\%), social networks (38.5\%), blogs $(9.4 \%)$ and discussion forums $(7.0 \%)$. 
Except of shopping habits and aspects of information and relationship to the information, in this research were tested customers satisfaction about availability, quality and diversification of organic products.

The highest number of customers is satisfied. They are the most satisfied with quality, than with availability and the less with diversity of organic products (table 1).

Table 1. Satisfaction of customers with organic products (availability, quality, diversity)

\begin{tabular}{|l|l|l|l|}
\hline \multicolumn{1}{|c|}{ Answers } & $\begin{array}{c}\text { How satisfied } \\
\text { are you with the } \\
\text { availability of } \\
\text { organic products } \\
\text { in your city? }\end{array}$ & $\begin{array}{c}\text { How much are } \\
\text { you satisfied } \\
\text { with the quality } \\
\text { of organic } \\
\text { products? }\end{array}$ & $\begin{array}{c}\text { How satisfied } \\
\text { are you with the } \\
\text { diversity of organic } \\
\text { products that are } \\
\text { available to you? }\end{array}$ \\
\hline I am very satisfied (\%) & 7.5 & $\mathbf{1 0 . 8}$ & 7.5 \\
\hline I am satisfied (\%) & 53.5 & $\mathbf{6 4 . 3}$ & 50.2 \\
\hline I am not satisfied (\%) & 33.8 & 23.0 & $\mathbf{3 9 . 4}$ \\
\hline I am not at all satisfied (\%) & $\mathbf{5 . 2}$ & 1.9 & 2.8 \\
\hline Total (\%) & 100.0 & 100.0 & 100.0 \\
\hline
\end{tabular}

Source: Authors' calculations

\section{Demographics characteristics and purchasing habits of organic products}

By using Chi-square test was examined the influence of demographic characteristics of consumers in Serbia on purchase of organic products. Among the features that have been investigated in the work - gender, age, status, education, place of residence were found that significant influence had gender and age.

Based on the results obtained through a series of chi-square test were shown that women significantly more frequent purchases organic products than men $\left(\chi^{2}(400,3)=\right.$ $15.051, \mathrm{p}<0.01)$.

Additionally, the way of information is different between the sexes. Women are informed significantly more through electronic media, from people in environment, as well as professional literature, while men are informed more likely through the magazine. The internet is represented equally in both gender $\left(\chi^{2}(400,4)=15.013, p<0.01\right)$.

The relation of customers according to the purchase of organic products depends on the age groups. Results of Chi-square test showed that the customers in the category 21-30 years and 31-40 years more often bought in supermarkets and specialized stores. Customers of age 41-50 years and 51- 60 years more often purchase in the market place and directly from producers. While the customers, who have more than 60 years mainly purchase in market places and supermarket. We believe that these features are part of a wider pattern of the consumer, not just of purchasing organic products. The differences between groups are statistically significant $-\chi 2(400,16)=15.051, \mathrm{p}<0.05$.

Age of consumers is related to the reasons which encourage purchase of organic products $(\chi 2(400,16)=31.879, \mathrm{p}<0.05)$ Figure 1 . 
Figure 1. Correlation of reason purchasing of organic products and the age of the consumers

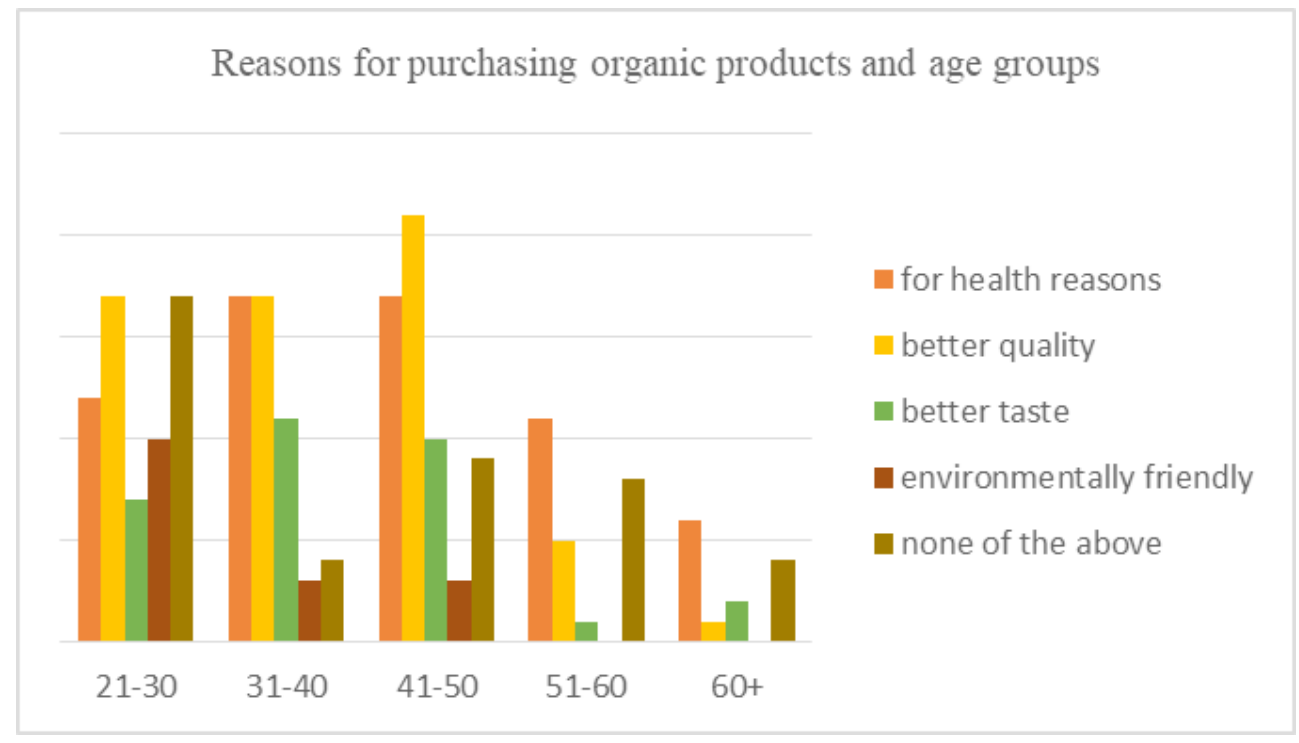

Source: Authors' calculations

Age is factor which influence on decision of customers for purchase organic products depends of traits of products. Customers younger than 30 years and aged between 41 and 50, respect the reputation of products. Also, customers old between 41 and 50 years equally respect price, reputation and reputation of products, while for customers older than 60 years the most important is price of products $(\chi 2(400,20)=35.175, \mathrm{p}<0.05)$.

Age of customers have statistically significant influence on the level of information and ways of information about organic food. The most affirmed customers are old between 41 to 50 years, than customers between 31 to 40 years of age and after that customers younger than 30 years. The value of Chi-square test was 24,913, a significance was less than 0.05 .

Differences exist according to the manner in which people of different ages informed. Customers younger than 30 years and those between 41 to 50 years of years, the mostly use the Internet and other electronic media $(\chi 2(400,16)=32.574, p<0.01)$.

From internet services, people younger than 30 years of age, the most often use social networks for information, while older people the most believe in the content on Web sites $(\chi 2(400,12)=31.297, \mathrm{p}<0.05)$.

Moreover, age of customers have influence on satisfaction with diversity of products that are available for purchase $(\chi 2(400,12)=25.493, \mathrm{p}<0.05)$. There are significant differences between age group of customers according to diversity of products. The less satisfied customers which are between 31 and 40 years old. 


\section{Discussions}

On the base of processed data of research can be said that both the hypotheses confirmed.

There is a preference for organic products in comparison to buying conventionally produced products. However, when we talk about the behavior of consumers, who participated in our study can be seen that less than half the customers often or always purchases organic products. This tells us that although there is a preference at the cognitive level, it not confirmed in behavior of customers.

The results corresponds to other investigation (Baudry et al., 2017; Paul et al., 2016). which reported that consumers are motivated for purchasing organic food from the reason to influence on technology o production food with reduction of environmental damages with their attitude in decision of food purchasing

When looking attitude towards organic products in our population can be concluded that the health and safety remain significant factors in the decision when purchasing organic products. This is illustrated by the fact that organic products are purchased primarily by recommendation and reputation. It means that customers very rarely make decision on the base of influence of advertisements, packaging, brand and even price.

In some research were found that consumers decide for purchasing on the base corporate social responsibility practice in interaction through non-financial information as well as that consumers prefer to accept to believe in the quality and price of products (Chang, 2017; Topp-Becker \& Ellis, 2017).

The processors and traders of organic products are the most interested in gaining consumers trust and meeting their expectation for high-quality and certified organic products. Marketing of organic products contribute to competiveness of producers and improve profitability allows appropriate prices. Marketing influenced by product policy, price policy, promotion policy and distribution policy.

The promotion of organic products is to achieve better recognition of products in on market, better information of consumers and their loyalty for purchase in the long term. In promotion the brand is very important indicator for recognition of the value of organic products. The priority in the food production is to establish a sound food safety management system as well as secure the food safety for consumers (Hsu et al., 2018).

The organic producers do not use synthetic pesticides, and since consumers and retailers are largely unaware of this, which need explain directly by means of product leaflets, magazines, internet, electronic media. Also, they need suggest a specific and authentic technology of production and products which must respond to functional and added value attributes.

It is necessary that the chosen promotion instruments should be adjusted to the operational marketing objectives. It is also essential to emphasize that the chosen marketing mix should not be statically fixed and that it does not need to cover all marketing measures in all cases, but instead must adapt to the (changing) operational 
objectives. The costs of such measures vary considerably, depending on the country and local costs for public relations and other marketing activities. Producers of organic products can educate retailers how need efficiently give information to consumers, and to increase organic food purchase intentions (Chang \& Chang, 2017).

The decision based on internet data information in purchase of organic product very often induce caution and certain degree of justified mistrust in society. Internet is not sufficient source of information what shows a significant percentage of customers with a critical review of the information obtained in this way.

Statistically significant differences in gender and age show us how much the purchase, manner of purchase and information about organic products and further conditioned by demographic characteristics. Results show that for each age group and gender need take approach in a specific manner, respecting and taking into account their habits and types of information. It is likely that the differences obtained in relation to the purchase of organic products caused by the different habits that are part of the general behavior of different consumer groups.

Customers want to know about the added value, about proposition of selling, the social and ecological benefits, the production methods shelf-life and product prices, and the health benefits and to taste recipes (Grubor \& Djokić, 2016). Consumers believe that the organic food products are healthier than conventional products, and they are ready to pay more for such products (Sharma et al., 2016; Sarumathi, 2017).

There is different instruments which should be combined for a promotion about producer and potential customer of organic products, with different types of media at different times. The mix of instruments depends from business area, the products and the target groups and available budget:

- High-cost promotion: media advertising, sales and price promotions, merchandising;

- Medium-cost promotion: trade fairs, exhibitions, press receptions, open days, telephone sales;

- Low-cost promotion: press releases, newsletters leaflets, brochures and posters.

The desired product assortment can be based on one product or on a broad assortment. The broader the range, the less risky the marketing because selling activities are on different bases. There is the disadvantage, however, that broad assortments often lead to less specialization and the effects of economies of scale are reduced.

In Serbia there are resources for organic production and government support programs of production through different measure. The development of organic production in Serbia has to include a network of collaborators, led by the relevant ministry, through manufacturers, distributors, to consumers, to really great opportunities for the development of this industry in Serbia really take advantage. 


\section{Conclusions}

The results of research showed that there are different habits of customers of organic products. Differences between customers are expressed on the base: of their mode of information about organic products, the reasons for purchasing organic products, of their requirements for quality of products on the market, according to place of purchasing organic products. According to habits of consumers of different sex and age, status, education, place of residence were established differences. Female more often use information from electronic media, other people and professional literature, while male more often use magazine for information about characteristics of organic products. Also, customers under the age of 30 and those between 41 to 50 years old, mostly use the Internet and other electronic media $(\chi 2(400,16)=32.574, p<0.01)$.

Majority of consumers (71.8\%) in Serbia preferred to use organic products in comparison to conventionally produced products. They purchase organic products in different places: supermarkets $(30.5 \%)$, on market places $(25.4 \%)$ and in specialized shops $(23.5 \%)$. Significantly less number of customers purchases organic products directly from the manufacturer $(14.1 \%)$ or online $(6.6 \%)$. The customers' decision to purchase organic products was influenced by reliability of the manufacturer $(38 \%)$, price $(23 \%)$, personal preferences $(25.4 \%)$, assortment $(10.3 \%)$, and location $(3.3 \%)$.

Also, age of customers have influence on satisfaction with diversity of products that are available for purchase $(\chi 2(400,12)=25.493, \mathrm{p}<0.05)$. The less satisfied customers which are old between 31 and 40 years.

\section{Acknowledgements}

This study financed by Ministry of Education, Sci and Technology Development of Republic Serbia-Project TR 31092.

\section{Conflict of interests}

The authors declare no conflict of interest.

\section{References}

1. Babović, J. (2008). Agribusiness in Organic Production, Agromenagement and Quality Standards, Organic Production Marketing, Multifunctional and Rural Development - Agrotourism, Monograph, Organic Agriculture, Institute of Field and Vegetable Crops, Novi Sad. [in Serbian: Babović, J. (2008). Agrobiznis u organskoj proizvodnji, Agromenadžment i standardi kvaliteta, Marketing organske proizvodnje, Multifunkcionalni i ruralni razvoj - agroturizam].

2. Baudry, J., Péneau, S., Allès, B., Touvier, M., Hercberg, S., Galan, P., Amiot, M.J., Lairon, D., Méjean, C. \& Kesse-Guyot, E. (2017). Food choice motives when purchasing in organic and conventional consumer clusters: focus on sustainable concerns (The NutriNet-Santé Cohort Study), Nutrients, 9 (2), 1-17. 
3. Božić, M., \& Vega Garcia, A. (2013). Organic agriculture in Austria. Journees Internationales du Marketing, 9, Marrakesh, Morocco, Conference paper.

4. Chang, H. H. (2017). Consumer socially sustainable consumption: the perspective toward corporate social responsibility, perceived value, and brand loyalty. Journal of Economics and Management, 13 (2), 167-191.

5. Chang, S.H. \& Chang, C.W. (2017). The strength, green expertise, and interpersonal influences on the purchase of organic food in an emerging market. British Food Journal, $119(2) 284-300$.

6. Dumea, A-C. (2012). Factors Influencing Consumption of Organic Food in Romania. The USV Annals of Economics and Public Administration, 12, 107-113.

7. Food and Agriculture Organization of the United Nations, FAO / WHO. (1999). "Guidelines for the production, processing, labeling and marketing of organically produced foods", Codex Alimentarius Commission, FAO, p. 2, available at:

8. http://www.codexalimentarius.net/download/standards/360/CXG032e.pdf

9. Golijan, J. \& Dimitrijević, B. (2018). Global organic food market. Acta Agriculturae Serbica, XXIII, 46, 125-140.

10. Grubor, A., Djokić, N. (2016). Organic food consumer profile in the Republic of Serbia. British Food Journal, 118 (1), 164-182.

11. Hsu, S.Y., Chang, C-C. \& Lin, T.T. (2018). Triple bottom line model and food safety in organic food and conventional food in affecting perceived value and purchase intentions. British Food Journal, doi.org/10.1108/BFJ-07-2017-0403

12. Kalentić, M., Stefanović, E., Simić, I., \& Maerz, U. (2014). Organic Agriculture in Serbia 2014. National Organic Production Development Organization "Serbia Organica”, Belgrade. [in Srbian: Kalentić, M., Stefanović, E., Simić, I., \& Maerz, U. (2014). Organska poljoprivreda u Srbiji 2014].

13. Kovačević, D. (2011). Contemporary concepts of sustainable agriculture development. permanent seminar of the Academy of Engineering Sciences of Serbia (AINS) http://www.ains.rs/predavanja/Dusan $\% 20 K o v a c e v i c \% 20$ predavanje $\% 20$ AINS.pdf [in Serbian: Kovačević, D. (2011). Savremeni koncepti održivog razvoja poljoprivrede].

14. Law on Organic Production, (2010). The official Journal RS, No. 30/10,

15. Michelsen, J., Hamm, U., Wynen, E. \& Roth, E. (1999). The European Market for Organic Products: Growth and Development. Organic Farming in Europe: Economics and Policy, 7, pp. 199, University of Hohenheim, Germany, Hohenheim.

16. Oljača, S. (2015). Control and certification in organic production in Serbia: project Improvement of organic agricultural production in Western Serbia through education of agricultural producers. Ministry of Agriculture and Environmental Protection, available at: http://arhiva.nara.ac.rs/handle/ [in Serbian: Oljača, S. (2015). Kontrola i sertifikacija u organskoj proizvodnji u Srbiji: projekat Unapređenje organske poljoprivredne proizvodnje u zapadnoj Srbiji putem edukacije poljoprivrednih proizvođača].

17. Paul, J., Modi, A. \& Patel, J. (2016). Predicting green product consumption using theory of planned behavior and reasoned action. Journal of Retailing and Consumer Services, 29, 123-134. 
18. Petrescu, A.G., Oncioiu, I. \& Petrescu, M. (2017). Perception of Organic Food Consumption in Romania. Foods, 6, 42. doi:10.3390/foods6060042

19. Phillip, B., \& Dipeolu, A. O. (2010). Willingness to pay for organic vegetables in Abeokuta, South West Nigeria. African Journal of Food, Agriculture, Nutrition and Development, Vol. 11, Nairobi.

20. Rosona, T. \& Gebresenbet, G. (2018). Swedish Consumers' Perception of Food Quality and Sustainability in Relation to Organic Food Production. Foods, 7, 54; doi:10.3390/foods 7040054

21. Sarumathi, S. (2017). A study on consumer's knowledge and willingness to pay for organic food products (in Pondicherry region). International Journal of Innovative Research in Management Studies (IJIRMS), 1(12), 35-40.

22. Schleenbecker, R., Hamm, U. (2013). Consumers' perception of organic product characteristics. A review. Appetite, 71, 420-429.

23. Schmid, O., Hamm, U., Richter, T. \& Dahlke, A. (2004). Organic Marketing Initiatives and Rural Development: A Guide to Successful Organic Marketing Initiatives. FiBL, p. 46. Frick.

24. Sharma, S., Shukla, R., Leua, A., Parmar, G., \& Chaudhari, B. (2016). Consumers' awareness and opinion regarding organic food products in south Gujarat. International Journal of Farm Sciences, 6(3), 206-215.

25. Simić, I. (2017). Organic Agriculture in Serbia At a Glance 2017. National Association Serbia Organica, Novi Sad. [ in Serbian: Simić, I. (2017). Organska poljoprivreda u Srbiji, ukratko 2017].

26. Sudarević, T., \& Davčik, St.N. (2005). Labeling of Organic Agricultural Products in Serbia. Annals of the Faculty of Economics in Subotica, 14, 79-86. [in Serbian: Sudarević, T., \& Davčik, St.N. (2005). Obeležavanje organskih poljoprivrednih proizvoda u Srbiji].

27. Sudarević, T., Salai, S., \& Pupovac, Lj. (2011). Marketing Aspects of Supply of Organic Agricultural Products in Serbia and the Environment. Annals of the Faculty of Economics in Subotica, 47(26), 36-37. [in Serbian: Sudarević, T., Salai, S., \& Pupovac, Lj. (2011). Marketing aspekti ponude organskih poljoprivrednih proizvoda u Srbiji i okruženju]

28. Topp-Becker, J. \& Ellis, J.D. (2017). The role of sustainability reporting in the agrifood supply chain. Journal of Agriculture and Environmental Sciences, 6 (1), 17-29

29. Vlahović, B. \& Puškarić, A., (2013). Organic agriculture - the chance for agribusiness, Novi Sad, Department of Economy, Novi Sad. [in Serbian: Vlahović, B., \& Puškarić, A., (2013). Organska poljoprivreda-šansa za agrobiznis].

30. Vlahović, B., Tomić, D., \& Popović V. (2010). Situation and Perspectives of Organic Agriculture Products. Proceedings, Fourth Forum on Organic Production, Selenča [in Serbian: Vlahović, B., Tomić, D., \& Popović V. (2010). Stanje i perspektive potrošnje proizvoda organske poljoprivrede].

31. Willer, H., \& Lernoud, J. (2014). The World of Organic Argiculture. Statistics \& Emerging Trends 2014. Research Institute of Organic Argiculture $(F i B L)$ and International Federation of Organic Argiculture Movements (IFOAM), Frick 
32. Xie, B.;Wang, L., Yang, H., Wang, Y. \& Zhang, M. (2015). Consumer perceptions and attitudes of organic food products in Eastern China. British Food Journal, 117, $1105-1121$.

33. Zarić, V., \& Mijajlović, J. (2014). Consumer attitudes towards organic products in Kraljevo municipality. [in Serbian: Zarić, V., \& Mijajlović, J. (2014), Stavovi potrošača prema organskim proizvodina u opštini Kraljevo] Agroekonomika, 43(63-64), 136-144. 